\title{
A SCALE TO MEASURE THE ATTITUDE OF FARMERS TOWARDS
}

\section{VEGETABLE SUPPLY CHAIN MANAGEMENT}

\section{R. KIRAN ${ }^{1} \&$ S. D. SIVAKUMAR ${ }^{2}$}

${ }^{1}$ Research Scholar, Department of agricultural and Rural Management, TNAU, Coimbatore, Tamil Nadu, India

${ }^{2}$ Professor and Head, Department of Social Sciences, ADAC \& RI Trichy, TNAU, Tamil Nadu, India

ABSTRACT
Attitude of an individual determines its acceptance, adoption, continuance and rejection. Attitude is the degree
of positive or negative effect associated with some psychological object. This study was designed, to develop a scale to
measure the attitude of farmers towards vegetable supply chain management. Edward's (1969) equally appearing interval
scale was adopted to develop the scale. The final scale comprised of ten statements. This scale was standardized for
administration.
KEYWORDS: Attitude; Supply Chain Management \& scale

Received: Oct 10, 2017; Accepted: Oct 30, 2017; Published: Nov 17, 2017; Paper Id.: IJESRDEC201710

\section{INTRODUCTION}

Farmers are the most potent stakeholder of vegetable supply chains. Hena and Peeyush (2014) described Supply chain management as a wide business process encompassing planning, implementing and controlling the operations of the supply chain which aims at providing the consumers with desirable goods and commodities. Supply chain management includes movement and storage of raw materials, inventory and finished goods from producers to consumers. Supply chain management can be explained as the flow of plans, materials and services from the supplier to the consumer including the close cooperation between the various entities in supply chain. Supply chain management offers options for improving the efficiency of farmers. There exist variations in the aspirations and expectations of farmers. Their varying degrees of attitude decide their expectations and aspirations. The successful involvement of farmers in supply chain activities rests on their attitudinal dispositions. Hence understanding their attitude is a prime factor.

All port (1935) defined attitude as mental readiness, ordered through long experience, and also stimulate in one direction or dynamics influence upon the individual's response to all objects with which it is related. Thur Stone (1946), explained attitude as the degree of positive or negative effect associated with some psychological object. Oskamp (1977) reported that, there are three components of attitude. The first component is cognition, which refers to ideas, beliefs, and perceptual responses about an attitude object. The second component is affect, which is related to a person's feelings and emotions about an object. Third is behaviour, which is the tendency to take action. According to Rafiepour (1993), attitude means a set of tendencies, views, and beliefs of an individual about his/her environmental factors. These tendencies and beliefs will be stabilized based on environmental effect, the gained experiences and the period of time. Siebert et al., (2006) described attitude as a combination of subjectively perceived factors that influence the farmer such as interests, values, norms, problem 
awareness and self-perception. According to Ahnstrom et al., (2008) attitude implied readiness to act or a mind-set that is used by an actor, to act and judge in situations of decision making. Farmers attitudes have an impact, on the acceptance of sustainable agriculture as a new technique to cultivate crops and rear live stock (Sadatiet al., 2010).

Large retail chains like Reliance Fresh, Food Bazaar, More, Easy day, Spencer's, Spar and HOPCOMS also have networking with farmers for direct sourcing of vegetables. Hence effective participation of farmers is an important factor in deciding the effectiveness of any vegetable supply chain. Considering the above facts research was carried out with the prime objective to develop an attitude scale in order to understand the varying degrees of attitude of farmers towards vegetable supply chain management.

\section{RESEARCH METHODOLOGY}

\section{Collection of Attitude Items}

A scale was developed to measure the attitude of farmers towards vegetable supply chain management. The scale was constructed by following 'Equal Appearing Interval' scaling technique, developed by Thurstone and Chave(1929). For the purpose of this study, attitude was operationalized as the mental disposition of the farmers about vegetable supply chain management in varying degrees of favourableness or unfavourableness. Possible statements concerning the psychological object i.e. "Vegetable Supply Chain Management" with respect to economic benefits, employment opportunities, resource utilization, risk management, commercial orientation etc., were collected based on review of literature, discussion with experts involved in supply chain management. Totally, 45 statements were collected, organized and structured in the form of items. The items were screened by following the informal criteria, suggested by Edwards (1969) for editing the statements to be used in the construction of the attitude scale. Based on the screening, 30 items were finally selected, which formed the universe of content.

\section{Item Scoring and Computation of Scale Values and Q Values}

The 30 statements were then subjected to Judge's opinion on a five-point continuum, ranging from most unfavourable to most favourable. The list of statements was sent to 50 judges comprising of scientists of State Agricultural Universities and ICAR Research Institutes. Of the 50 judges, 30 judges responded by sending their judgments. By applying the formula as suggested by Thurstone and Chave (1929), the scale values and Q values were computed for the 30 statements.

\section{Scale Value}

$S=1+\left\{\left(0.50-\Sigma P_{b}\right) / P_{w}\right\} i$

Where,

$\mathrm{S}=$ the median /Scale value of the statement

$\mathrm{l}=$ the lower limit of the interval in which the median falls

$\Sigma \mathrm{P}_{\mathrm{b}}=$ the sum of the proportions below the interval in which the median falls

$\mathrm{P}_{\mathrm{w}}=$ the proportion within the interval in which the median falls

$\mathrm{i}=$ the width of the interval and is assumed to be one (1). 
Thurstone and Chave (1929), used the interquartile range (Q) as a measure of the variation of the distribution of judgments for a given statement. The inter quartile range contains the middle $50 \%$ of the judgments. To determine the value of $\mathrm{Q}, 75^{\text {th }}$ and $25^{\text {th }}$ centiles should be obtained.

$$
\begin{aligned}
& \mathbf{Q}=\mathbf{C}_{75}-\mathbf{C}_{25} \\
& \mathbf{C}_{75}=\mathbf{l}+\left\{\left(0.75-\Sigma \mathbf{P}_{\mathrm{b}}\right) / \mathbf{P}_{\mathrm{w}}\right\} \mathbf{i}
\end{aligned}
$$

Where,

$\mathrm{C}_{75}=75^{\text {th }}$ centile

$l=$ the lower limit of the interval in which the $75^{\text {th }}$ centile falls

$\Sigma \mathrm{P}_{\mathrm{b}}=$ the sum of the proportions below the interval in which the $75^{\text {th }}$ centile falls

$\mathrm{P}_{\mathrm{w}}=$ the proportion within the interval in which the $75^{\text {th }}$ centile falls

$\mathrm{i}=$ the width of the interval and is assumed to be one (1).

$\mathrm{C}_{25}=\mathrm{l}+\left\{\left(0.25-\Sigma \mathbf{P}_{\mathrm{b}}\right) / \mathbf{P}_{\mathrm{w}}\right\} \mathbf{i}$

Where,

$\mathrm{C}_{25}=25^{\text {th }}$ centile

$\mathrm{l}=$ the lower limit of the interval in which the $25^{\text {th }}$ centile falls

$\Sigma \mathrm{P}_{\mathrm{b}}=$ the sum of the proportions below the interval in which the $25^{\text {th }}$ centile falls

$\mathrm{P}_{\mathrm{w}}=$ the proportion within the interval in which the $25^{\text {th }}$ centile falls

$\mathrm{i}=$ the width of the interval and is assumed to be one (1).

The computed scale and Q values are tabulatedin Table 1.

Table 1: Computation of Equal Appearing Intervals

\begin{tabular}{|c|c|c|c|c|c|c|}
\hline $\begin{array}{c}\text { Statement } \\
\text { No. }\end{array}$ & $\begin{array}{c}\mathbf{S} \\
\text { Value }\end{array}$ & $\begin{array}{c}\mathbf{Q} \\
\text { Value }\end{array}$ & $\begin{array}{c}\text { Difference B/W } \\
\text { Successive } \\
\text { Intervals of S } \\
\text { Value }\end{array}$ & $\begin{array}{c}\text { Cumulative } \\
\text { Value of the } \\
\text { Differences }\end{array}$ & $\begin{array}{c}\text { Equal } \\
\text { Appearing } \\
\text { Class } \\
\text { Interval }\end{array}$ & Compartments \\
\hline $\mathbf{3 0}$ & $\mathbf{3 . 5 0}$ & $\mathbf{2 . 0 2}$ & $\mathbf{0 . 1 9}$ & $\mathbf{0 . 1 9}$ & $\mathbf{0 . 1 8 4}$ & I \\
\hline $\mathbf{2 9}$ & $\mathbf{3 . 3 1}$ & $\mathbf{1 . 1 1}$ & $\mathbf{0 . 0 6}$ & $\mathbf{0 . 2 5}$ & $\mathbf{0 . 3 6 8}$ & \multirow{2}{*}{ II } \\
\hline 5 & 3.25 & 1.75 & 0.04 & 0.29 & & \multirow{2}{*}{ III } \\
\hline 11 & 3.21 & 1.81 & 0.00 & 0.29 & & \multirow{2}{*}{ IV } \\
\hline 22 & 3.21 & 1.21 & 0.01 & 0.30 & & \\
\hline 7 & 3.20 & 1.99 & 0.09 & 0.39 & & \\
\hline $\mathbf{1 3}$ & $\mathbf{3 . 1 1}$ & $\mathbf{1 . 3 9}$ & $\mathbf{0 . 0 6}$ & $\mathbf{0 . 4 5}$ & $\mathbf{0 . 5 5 2}$ & \\
\hline 3 & 3.05 & 0.83 & 0.16 & 0.61 & & \\
\hline 12 & 2.89 & 1.66 & 0.03 & 0.64 & & V \\
\hline 8 & 2.86 & 0.83 & 0.00 & 0.64 & $\mathbf{0 . 7 3 6}$ & VI \\
\hline $\mathbf{1 5}$ & $\mathbf{2 . 8 6}$ & $\mathbf{0 . 3 7}$ & $\mathbf{0 . 0 0}$ & $\mathbf{0 . 6 4}$ & $\mathbf{0 . 9 2 0}$ & \\
\hline 28 & $\mathbf{2 . 8 6}$ & $\mathbf{1 . 3 2}$ & $\mathbf{0 . 2 4}$ & $\mathbf{0 . 8 8}$ & & \\
\hline 10 & 2.62 & 1.62 & 0.12 & 1.00 & & \\
\hline
\end{tabular}




\begin{tabular}{|c|c|c|c|c|c|c|}
\hline 23 & 2.5 & 1.15 & 0.08 & 1.08 & 1.104 & \\
\hline 20 & 2.42 & 1.97 & 0.11 & 1.19 & 1.288 & VII \\
\hline 14 & 2.31 & 1.64 & 0.15 & 1.34 & & \multirow{5}{*}{ VII } \\
\hline 18 & 2.16 & 2.37 & 0.00 & 1.34 & & \\
\hline 26 & 2.16 & 0.96 & 0.02 & 1.36 & & \\
\hline 19 & 2.14 & 0.95 & $\begin{array}{l}0.02 \\
\end{array}$ & 1.38 & 1.472 & \\
\hline 16 & 2.12 & 1.03 & 0.09 & 1.47 & & \\
\hline 24 & 2.03 & 0.97 & 0.07 & 1.54 & 1.656 & \multirow{2}{*}{ IX } \\
\hline 25 & 1.96 & 1.43 & 0.09 & 1.63 & & \\
\hline 2 & 1.87 & 0.97 & 0.03 & 1.66 & & \multirow{6}{*}{$X$} \\
\hline 4 & 1.84 & 0.77 & 0.01 & 1.67 & 1.840 & \\
\hline 6 & 1.83 & 1.27 & 0.03 & 1.70 & & \\
\hline 17 & 1.80 & 1.20 & 0.07 & 1.77 & & \\
\hline 9 & 1.73 & 0.99 & 0.06 & 1.83 & & \\
\hline 21 & 1.67 & 0.98 & 0.01 & 1.84 & & \\
\hline 1 & 1.66 & 0.541 & 1.66 & 3.50 & & \\
\hline
\end{tabular}

A large Q value indicated the disagreement among the judges with regard to the degree of the attribute possessed by a statement and therefore it was taken as an indication that there was something wrong with the statement. Thurstone and Chave (1929) regarded large Q values, primarily as an indication that, the statement was ambiguous. Large Q values may result from the fact that, the statement is interpreted in more than one ways by the judges, when making their judgments.

\section{Selection of Attitude Items}

The attitude items to be included in the final attitude scale were selected based on the following Criteria.

- The statements selected should represent the universe of content with respect to vegetable supply chain management.

- The statements selected should adequately represent the domains such as economic benefits, employment opportunities, resource utilization, risk management, commercial orientation etc.

- The scale values of the selected attitude items should have equal appearing interval i.e. distributed uniformly along the psychological continuum.

- $\quad$ Those items with high Scale values (S) and smaller Q values should be selected as far as possible.

- There should be more or less equal number of statements with favorable and unfavorable attitudes as far as possible.

An objective methodology was devised in order to select the attitude items keeping in mind the criteria mentioned. The scale values were arranged in ascending order of magnitude and the difference between the successive scale values and the cumulative total of the computed differences were worked out. Considering the time limitation from farmers' point of view, ten statements were selected to constitute the attitude scale. Since the selected scale values should have equal appearing interval and distributed uniformly along the psychological continuum, it was necessary to form ten compartments so as to select ten statements atone statement from each compartment. The basis for forming the compartment was that, each compartment should be equally spaced in the continuum. For this purpose, the cumulative total was divided by ten, which worked out to 0.184; and this formed the width of the class intervals. Each class interval represented a compartment for the selection of the attitude items. 
To select the attitude items from the ten compartments the scale values $(\mathrm{S})$ and the corresponding $\mathrm{Q}$ values were considered. Based on the criteria already mentioned, items having high scale values $(\mathrm{S})$ and low $\mathrm{Q}$ values were selected at one item from each compartment. Care was taken to ensure that the selected items represented the universe of content and covered different aspects of Vegetable supply chain management. Thereby, ten items were selected with equal appearing interval and with a uniform distribution along the psychological continuum. The attitude scale thus constructed is given in Table 2.

\section{Reliability and Validity of the Scale}

The reliability of the scale was determined by 'split- half' method. The split-half method is regarded by many as the best of the methods for measuring reliability (Garrett and Woodworth, 1969). The ten selected items to measure the attitude were divided into two equal halves by odd-even method (Singh, 2008). The two halves were administered separately to 30 farmers engaged in Vegetable supply chain management in a non-sample area. The scores were subjected to product moment correlation test in order to find out the reliability of the half-test. The half-test reliability coefficient (r) was 0.570 , which was significant at five per cent level of probability. Further, the reliability coefficient of the whole test was computed using the Spearman-Brown prophecy formula. The whole test reliability $\left(\mathrm{r}_{\mathrm{tt}}\right)$ was 0.726 . According to Singh (2008), when the mean scores of the two groups are of narrow range, a reliability coefficient of 0.50 or 0.60 would suffice. Hence, the constructed scale is reliable as the $r_{t t}$ was greater than 0.60 .

Content validity referred to the representativeness or sampling adequacy of the content of a measuring instrument (Kerlinger 2007). Content validation was carried out, by subjecting the selected ten attitude items to judge's opinion. Experts in the selected field of study were the judges. They were asked to indicate the extent to which each attitude item covered the different aspects of vegetable supply chain management or judge each item for its presumed relevance to the property being measured. The responses were obtained on a four point continuum of 'most adequately covers', 'more adequately covers', 'less adequately covers' and 'least adequately covers'. Scores of 4, 3, 2 and 1 were given for the points on the continuum respectively. Totally 30 judges responded by sending their judgments. The mean score (2.5) was fixed as the basis for deciding the content validity of the scale i.e. if the overall mean score of the attitude items as rated by the judges was above 2.5, the scale will be declared as valid and if not otherwise. In the present case, the overall mean score was worked out as 3.0 therefore, the constructed attitude scale is said to be valid.

Table 2: Final Set of Attitude items Selected with Corresponding Scale and Q Values

\begin{tabular}{|c|c|c|l|l|}
\hline $\begin{array}{c}\text { Statement } \\
\text { No. }\end{array}$ & $\begin{array}{c}\text { Scale } \\
\text { Value }\end{array}$ & $\begin{array}{c}\text { Q } \\
\text { Value }\end{array}$ & \multicolumn{1}{|c|}{ Statement } & Nature of Statement \\
\hline 30 & 3.50 & 2.02 & $\begin{array}{l}\text { Farmers have to sell at low price due to } \\
\text { high perishability of the vegetables }\end{array}$ & Unfavorable \\
\hline 29 & 3.31 & 1.11 & $\begin{array}{l}\text { Participating in supply chains helps } \\
\text { farmers to have strong research and } \\
\text { extension linkages }\end{array}$ & Favorable \\
\hline 13 & 3.11 & 1.39 & $\begin{array}{l}\text { Crop planning and time management } \\
\text { are followed by farmers participating in } \\
\text { the supply chain }\end{array}$ & Favorable \\
\hline 15 & 2.86 & 0.37 & $\begin{array}{l}\text { Lack of coordination among farmers to } \\
\text { increase their bargaining power in the } \\
\text { supply chain }\end{array}$ & Unfavorable \\
\hline 28 & 2.86 & 1.32 & $\begin{array}{l}\text { Participating in supply chains enables } \\
\text { farmers to have better contact with the } \\
\text { govt. officials }\end{array}$ & Favorable \\
\hline
\end{tabular}




\begin{tabular}{|c|c|c|l|l|}
\hline \multicolumn{7}{|l|}{ Table 2: Contd., } \\
\hline 23 & 2.50 & 1.12 & $\begin{array}{l}\text { Supply chain also enables procurement } \\
\text { of vegetables even in small quantities } \\
\text { from farmers }\end{array}$ & Favorable \\
\hline 20 & 2.42 & 1.97 & $\begin{array}{l}\text { Transparency is lacking in supply chain } \\
\text { management approach }\end{array}$ & Unfavorable \\
\hline 19 & 2.14 & 0.95 & $\begin{array}{l}\text { Supply of packaging materials in the } \\
\text { supply chain is not regular }\end{array}$ & Unfavorable \\
\hline 24 & 2.03 & 0.97 & Supply chain makes post-harvest losses & Unfavorable \\
\hline 04 & 1.84 & 0.77 & $\begin{array}{l}\text { Supply chain management ensures to } \\
\text { provide technical guidance to farmers }\end{array}$ & Favorable \\
\hline & & & & \\
\hline
\end{tabular}

\section{Administration of the Scale}

The ten attitude items selected were arranged randomly in order to avoid biased responses. The scale could be built on a five point continuum, as 'most favourable, 'favourable', 'neutral' 'unfavourable' and 'most unfavourable' was used as response categories. The scores for favourable statements may be given the scores as most favourable-7, favourable-5, neutral-4, unfavourable-3 and most unfavourable-1. For unfavourable statements the scoring procedure can be reversed. The score obtained for each statement is summed up to arrive at the attitude score, for the respondents. The score ranged from 70 (maximum) to 10 (minimum). The responses are grouped as less favourable, moderately favourable and highly favourable based on the cumulative frequency method.

\section{CONCLUSIONS}

This study was designed to develop a scale to measure the attitude of farmers, towards vegetable supply chain management. Edward's equally appearing interval scale was adopted to develop the scale. The final scale comprised ten statements. This scale was standardized for administration.

\section{REFERENCES}

1. Ahnstrom, J., Hockert, J., Bergea, H. L., Francis, C. A., Skelton, P. and Hallgren, L.(2008). Farmers and nature conservation: What is known about attitudes, context factors and actions affecting conservation? Renewable Agriculture and Food Systems, 24:38-47.

2. Allport, G. W. (1935). Attitudes. In C. Murchison (Ed.), Handbook of Social Psychology. Worcester, MA: Clark University Press, p.798-844.

3. Edwards L. Allen.(1969). Techniques of attitude scale construction. VakilsFeffer and Simons Pvt Ltd., Bombay, India, p. 83117.

4. Garrett, H. E. and Woodworth, R. S. (1969). Statistics in Psychology and Education, VakilsFeffer and Simons Pvt. Ltd., Bombay, p.329.

5. Hena, Imtiyaz. andPeeyush, Soni. (2014). Marketing Supply Chain Management of Brinjal: Challenges and Opportunities. International Journal of Management, 5(2): 116-125.

6. Kerlinger, F. M. (2007). Foundation of Behavioural Research. Rinehart and Winston. Inc. New York.

7. Naidu, S.(2015). Scope of Supply Chain Management in Fruits and Vegetables in India. Journal of Food Processing \& Technology, 6 (3): 1-7. 
8. Oskamp, S. (1977). Attitudes and opinions. Englewood Cliffe, NT: Prentice-Hall, p.15.

9. Rafiepour, F. (1993). Rural tendency evaluation to Jahad e Sazandagi. Tehran, Arganoon edition, p. 50-58.

10. Sadati, S. A., Hosain, S. F., Ali, A., \&Sadati, S. A. (2010). Farmer's attitude on sustainable agriculture and its determinants: a case study inBehbahan County of Iran. Research Journal of Applied Sciences, Engineering and Technology, 2(5):422-427.

11. Siebert, R., Toogood, M., Knierim, A.(2006). Factors Affecting European Farmers' Participation in Biodiversity Policies. SociologiaRuralis46: 318-340.

12. Singh, A. K. (2008). Tests, measurements and research methods in behavioural sciences. Tata McGraw-Hill Publishing Company Limited, New Delhi.

13. Thurstone L. L., and Chave E. J.,(1929). "The measurement of attitude: a psychological method and some experiments with a scale for measuring attitude toward the church". University of Chicago Press, Chicago, p. 1-21.

14. Thurstone, L. L.(1946). Comment. American Journal of Sociology, 52: 39-50. 
